\title{
NEW PUBLIC MANAGEMENT AS A GLOBAL EDUCATION POLICY: ITS ADOPTION AND RE-CONTEXTUALIZATION IN A SOUTHERN EUROPEAN SETTING
}

Antoni Verger and Marta Curran

Department of Sociology. Universitat Autònoma de Barcelona

\section{Introduction}

New Public Management (NPM) is one of those policy ideas that, along with publicprivate partnerships, child-centred pedagogies and standardized testing, has acquired 'global status' in education policy agendas (cf Steiner-Khamsi, 2010). Since the 1980s, most countries in the world have experimented with NPM-like reforms, to the point that some consider NPM as an "administrative revolution" or a new post-bureaucratic policy paradigm (Haque 1996, Hood and Peters 2004).

NPM is a philosophical corpus of managerial ideas that aims at driving public sector reform in a range of policy areas. It can be broadly defined as "an approach in public administration that employs knowledge and experiences acquired in business management and other disciplines to improve efficiency, effectiveness, and general performance of public services in modern bureaucracies" (Vigoda, 2003, p. 813). Education, as one of the sectors of public administration with the largest budgets and number of personnel in most countries, has been widely affected by reforms inspired by NPM postulates. In many places, NPM has drastically altered the governance of education institutions, and principles like school autonomy, result-based performance or client's choice have deeply penetrated the regulation of education systems (Maroy, 2009; Tolofari, 2005).

This article looks at the phenomenon of the globalization of NPM by analysing how, why and under what circumstances NPM has been adopted and implemented in particular educational contexts. Specifically, this study focuses on the policy transfer and re-contextualization of NPM in the Spanish educational context. Most research on NPM reforms in education focuses on Anglo-Saxon and Nordic-European countries; while not much has been written regarding Southern European contexts, where the welfare state has followed a very different tradition and trajectory. Since the Spanish education system is highly decentralized our study focuses on Catalonia. The Catalan case is especially appropriate due to the fact that this region pioneered the introduction 
of NPM reforms within the Spanish educational system (Maragall and Colomé, 2013). In fact, Catalonia experimented with NPM reforms even when it potentially conflicted with the Spanish legal framework on public service. Nevertheless, on-going education reforms in Spain are scaling-up NPM at the state level.

This article is structured in three main sections. In the first, we briefly review the literature on NPM adoption and implementation from a global education policy perspective. In the second section, we present the main features of the Spanish education system, and develop the Catalan case study by tracing the NPM policy adoption and implementation processes that have taken place there in the last decade. Here, we focus on the role played by governmental actors and other key stakeholders, on the rationales and strategies behind their decisions and positions, and on the way these elements have interacted with a shifting political and economic environment. Third, we discuss our results and draw conclusions.

The paper shows that the reasons for adopting NPM in the Spanish context are not so different from those prevailing in other European settings. Counter-intuitively, although NPM is a reform programme traditionally associated with right wing ideologies, in Catalonia, it has been adopted and regulated by a social democratic government. In fact, something similar has happened before in other European countries, such as Sweden or the UK, where social democrats embraced NPM, among other reasons, as an attempt to strengthen the legitimacy of the welfare state and continue to use it as their main political asset. However, for a combination of political, institutional and economic reasons that we will detail below, the NPM reforms have been established and implemented unevenly and contradictorily in Catalonia.

Our analysis is based on intensive fieldwork that includes thirteen interviews with key education stakeholders (individuals interviewed include Ministry of Education officials, policy entrepreneurs, teachers' unions and the school principals' lobby) that were conducted between February 2013 and January 2014, as well as document analysis of policy briefings, press releases, media kits and legal documents. The case study of the NPM penetration in Catalonia has been structured by following the process-tracing method. This method has guided us in the systematization of information obtained through empirical observation, and has enabled us to link the key events in the policy process with the resulting impact it has had on the education system (cf Beach and Pedersen 2013). Interview data has become an indispensable resource to reconstruct the policy change process under observation, especially due to the absence of a transparency culture in Spanish public administration. The data we have compiled has been analysed using Atlas-ti. 


\section{NPM as a global education policy idea}

From a global education policy perspective, the analysis of NPM reforms raises the following questions: How and why has NPM become inserted in global agendas? Why do local policy-makers and practitioners from different world locations adopt NPM policies? What are the mediating factors and institutions affecting the translation and re-contextualisation of these policies into particular sectors? What are the specific difficulties associated with the implementation of NPM ideas in local contexts? (Lingard and Rizvi 2010, Verger et al., 2012). In this section, we review some of the answers already provided to these questions in the literature.

Despite the existence of different waves of managerialist public sector reforms during the $20^{\text {th }}$ Century, many consider NPM to have begun to penetrate western industrialized countries in the 1980s. Among its early-adopters, we find the US, the UK and Canada, all of them being governed by the New Right at that time (Tolofari, 2005). The main rationale supporting NPM reforms then was economic and fiscal austerity, as it was argued that managerial reforms would contribute to efficiency gains in the public sector. Another incentive for the New Right to embrace NPM was that, by fragmenting public services, they could undermine the power of unions and professional lobbies.

Later on, but under a similar rationale, international financial institutions such as the World Bank and the International Monetary Fund would disseminate NPM ideas across the developing world. NPM became a key component in the structural adjustment programmes promoted by these organizations. They embraced NPM because they considered that for more conventional macro-economic stability prescriptions to be effective, they would need to be combined with a public choice approach to public sector reform (Fine, 2006).

Thus, apparently, in the early years of NPM, budgetary discipline was the main driver of its dissemination and adoption, both in developed and developing contexts (Hendriks and Tops, 2003). However, some researchers point out that, in some cases, NPM adoption does not necessarily correlate with periods of economic crisis, and that instead there are motives of a political nature that are in play. For Klitgaard (2007) and Wiborg (2013), party politics and, specifically, the evolution of social democratic thinking in Europe, are key elements to understand the adoption of market-oriented reforms a la NPM in Scandinavian countries. These authors observe that social democratic governments in this region have adopted public sector reform ideas that originally came from the right as a way to try to modernize public education, public health or the pension system, introduce services differentiation and more choice options. Aware of the legitimacy crisis of the welfare state and the increasing social dissatisfaction with the bureaucratization of public services, social democrats have 
seen NPM as an instrument to both transform and protect the idea of the 'universal welfare state' as their most valuable political weapon.

"Social democratic governments decide upon reforms when the party elite perceive policy problems as a threat to the legitimacy of the universal welfare state. Political institutions, i.e., welfare policies, functioning as power resources, need to be legitimate otherwise they may work against basic political interests." (Klitgaard, 2007, p.172)

A similar argument can be made regarding the public sector reforms undertaken by New Labour when it began governing in the UK at the end of the 1990s (cf Clarke et al., 2000, McLaughlin et al., 2001)

The different faces of NPM in education: the case of school autonomy

The administrative values behind the NPM programme are efficiency, instrumental rationality and adaptability of systems. In terms of more concrete prescriptions, the NPM reform agenda implies:

"disaggregating separable functions into quasi-contractual or quasi-market forms, particularly by introducing purchaser/provider distinction; opening up provider roles to competition between agencies or between public agencies, firms and not-for-profit bodies; and deconcentrating provider roles to the minimum-feasible sized agency, allowing users more scope for 'exit' from one provider to another, rather than relying on 'voice' options to influence how public service provision affects them" (Kalimullah et al., 2012, p. 3)

Contrary to what many think, NPM policies do not imply a retreat of the state, rather, it is a question of the state changing its functions in relation to public services (Hudson, 2007). Instead of being seen as the direct provider of services, the state is expected to strengthen its role as regulator, evaluator and distributor of incentives to providers. In Osborne and Gaebler's (1993) famous words, the state should focus on "steering" rather than on "rowing" public services.

Despite these general principles and prescriptions, NPM adopts different forms and rules according to the particular sector on which it is transposed. In the education sector, NPM often means the promotion of school autonomy and a managerialist approach to school organization, market-driven competition between schools, outcomes-based incentives for schools and teachers and, overall, education services more oriented toward families' demands. In education, many see NPM reforms as an attack on welfare state traditions and as part of the global spread of neoliberalism, with its emphasis on greater consumer choice, efficiency, accountability and the 
privatization of public services. From this point of view, NPM would be a functional adaptation of the state to a more competitive environment, and a strategy to put education to work for a country's economic competitiveness (Hudson, 2007, Lingard and Rizvi 2010).

However, NPM ideas in education are often ambiguous and can include policy measures that do not exclusively have such a neoliberal connotation. This is the case of, for instance, 'school autonomy', which is one of the flagships in the NPM educational tool kit. Under the 'school autonomy' label, policies and practices of a very different nature can be accommodated. On the one hand, there is a managerial approach to school autonomy, also known as 'school-based management', which implies deconcentration of managerial responsibilities to the school level and their concentration in the school principal in particular. Like a manager of a private corporation, the principal should be able to manage the school's economic and human resources more independently, have the capacity to raise extra-funding for the school, and hire and fire teachers directly (Gunter and Forrester, 2009). From this perspective, school autonomy disempowers teachers in relation to the figure of the principal of the school, and can fragment the education system in the sense of differentiating the resources available to the different providers (Eurydice, 2007).

On the other hand, school autonomy also has a pedagogic focus and means giving schools the capacities to decide on the most suitable educational projects, curricular contents and evaluation systems according to the particularities and needs of the school based on the social context in which it is located. Here, school autonomy implies the professionalization of teachers' work, as they are conceived as autonomous intellectuals who decide on the main components of the teaching-learning process (Sleegers and Wesselingh, 1995). Thus, in contrast to the managerialist model, school autonomy would be here associated with progressive goals like professionalization and attention to diversity. In any case, both ideal types of school autonomy (the managerial and the pedagogic) can actually appear in rather mixed and hybrid forms.

Similar reflections on the dual nature and meanings of specific policies could be done in relation to other NPM measures such as the professionalization of school principals, or teachers' performance evaluation, to name a few.

\section{Recontextualizing NPM}

NPM, as any other global policy, is not being uniformly received and adopted in all places. Although global education policies present common features around the world, their effects are mediated by, among other contingencies, local history, politicoadministrative and ideational settings, and the complex interplay of global and local 
forces (Verger et al., 2012). For instance, public sentiments are very important when it comes to understanding the global spread of NPM, due to the fact that, as Kalimullah et al. (2012) state, "bureaucracy now has few supporters anywhere. Any solution offering a reduction in bureaucracy is likely to be popular (p.19)".

According to Peck and Theodore (2010) global policies mutate during their journeys, and 'rarely travel as complete packages, they move in bits and pieces - as selective discourses, inchoate ideas, and synthesized models- and they therefore "arrive" not as replicas but as policies already-in transformation' (p.170). Similarly, Ball (1998) considers that global policies are rarely translated into particular practices in pristine form since, beyond a fixed programme, they are part of an often-disputed technical and political debate that is highly contingent and situated.

Local contexts and, in particular, the agents that operate in those contexts are strategically selective. State and non-state actors operating at the local level have the capacity to tinker with and provide particular meanings to global ideas by recombining them with available local policies and practices (Campbell 2004). They can also try to instrumentalize global agendas, policies and frameworks to push for their particular policy preferences and interests. For instance, it is well documented that many governments have used the OECD/PISA results as a political opportunity to advance their pre-established policy preferences (Martens et al 2010), and 'make the case for education reforms at home that would otherwise be contested' (Grek, 2007, p. 35).

\section{The penetration of NPM reforms in Spanish education: the Catalan case}

The governance of Spanish education in context

Spain, together with Portugal, Greece and Italy, is part of a 'family of nations' (Castles, 1993) that share a similar historical background and similar socio-economic particularities. They were all ruled by authoritarian regimes during some period in the $20^{\text {th }}$ Century and experienced a delay in the process of modernization and in the expansion of their welfare states, including public education (Ferrera, 1996; Sotiropoulos, 2004). The Church has a strong influence in all of these countries, and is very present in the provision of education. In fact, in Spain, in the transition to democracy, the Catholic Church played a big role in education politics and in resulting reforms, even at the time that the socialist party was in power. In particular, in 1985, it influenced importantly the consolidation of a dual public education system in which private schools (mainly religious) could apply for public funds on the condition that they provide education without charging fees and without screening students.

This public-private partnership, which prevails in Spanish education since the 
middle of the eighties, has a clear efficiency purpose; in its time, it allowed for an important education expansion at a lower cost. However, there are also important drawbacks in its application. The admission criteria in publicly-funded private schools are weakly regulated, and many of these schools make families pay undercovered school fees (Benito and González 2007; Villarroya and Escardíbul, 2008). These practices are behind the high level of ethnic and socio-economic segmentation that prevails in the Spanish educational system (Bonal 2012), which is, at the same time, one of the most important causes of the low effectiveness of Spanish education (Calero 2006).

Today, around $30 \%$ of Spanish students in compulsory schooling are enrolled under the modality of publicly-funded private schools. Only $4 \%$ of students are, in fact, enrolled in fully private schools (MECD 2012). One of the milestones in the privatization of education process in Spain needs to be found in an ambitious education reform that was applied in 1990. This reform revolutionized the pedagogic methods - by mainstreaming constructivism - and expanded compulsory education for two more years. However, despite the education democratization effect that this reform had, it was not implemented with sufficient resources. This contributed to the deterioration of public schools and to middle class children exiting them to enrol in the more selective publicly-funded private sector (Fernández-Polanco 2007).

In Spanish public schools, the model of school direction is predominantly horizontal and non-professional. ${ }^{1}$ The 1985 Education Act placed an important emphasis on the idea of community participation at the school level, in great part as a reaction to the hierarchical model of leadership that prevailed during the Franco regime - with an authoritarian principal linked to the government. In this new scenario, perfectly ordinary teachers could be elected by the educational community to assume the school direction, ${ }^{2}$ and the school council became a central body in the governance of schools. The school council, which is made up of representatives of the entire educational community-including principals, teachers, parents, students, administrative personnel and other staff- makes important decisions regarding the everyday functioning of the school, including the definition of the school educational project, several items of the budget or school organization aspects.

Other Southern European countries experimented also with such a participatory model of educational governance during the 1980s (Eurydice, 2007; Reguzzoni, 1994).

\footnotetext{
${ }^{1}$ According to the OECD (2007), non-professional refers to a "system of designating school leaders with no prior training or profile".

${ }^{2}$ Although, with the 1995 reform principals had to meet a set of requirements and be accredited.
} 
However, in Spain, this governing body is being challenged due to the low levels of participation of its members (Frías del Vall, 2006, Gómez Llorente, 2006) and, in fact, the latest education reform has reduced its competences in favour of a greater professionalization of school leadership (cf. Ministerio de Educación, Cultura y Deporte 2013). The perceived lack of effectiveness of school councils, together with the growing demand of private education, has given legitimacy to those that advocate for the application of private sector management ideas into public schools. To many reformers, private schools are seen as the example to follow: they enjoy both managerial and organizational autonomy; they have strong leadership; the principal and the owners of the school directly hire the teachers they think can best contribute to the institutional project; and they can generate revenue by offering a range of services or through external donations.

Recent regulatory changes in Spain aim at re-centralizing school leadership and 'modernizing' the management and organization of schools by following NPM principles. In this terrain, the Catalan Education Act (2009) represents the most advanced and detailed regulatory framework. ${ }^{3}$ In the case study that we develop bellow, we analyse why and how NPM has penetrated the Spanish education context, and the Catalan one in particular. However, whether NPM policies, which have been widely adopted at the regulatory level, are actually in place is also an empirical question that needs to be responded. It needs to be acknowledged that, in this country, as in many other Southern European settings, the regulatory framework has advanced at a much faster path than have actual practices (Santos 1991). One of the reasons for this to happen is that, when education reforms are discussed in these settings, the state needs to respond to very different - and often conflicting - demands of a range of constituencies. This is something that has reinforced the contradictory character of education policy and, in particular, the existing gap between regulation and practice (Bonal and Rambla, 1996). In the following pages, we will also reflect on how these tensions have played out in the adoption and application of NPM reforms in Catalan education.

\section{The progressive government and the NPM revolution in Catalonia}

In 2001, the Catalan government - by then, in the hands of the Catalan conservative

\footnotetext{
3 Since the endorsement of the Spanish Constitution (1978), the State gradually transferred functions, services and resources to the regional authorities. Due to historical, political and cultural reasons, Catalonia, the Basque Country and Galicia achieved the highest level of education competences from the start, although it wasthe New Catalan Autonomy Act (2006) the one that gave Catalonia the capacity to pass its own education legislation.
} 
party - passed a Strategic Education Planning Decree that, among other things, aimed at decentralizing the distribution of teachers according to the needs of schools and, by doing so, eliminating the centralized approach to the allocation of teachers. The teachers' unions organized street protests and filed a complaint against the government for this measure. The three left-wing parties in the parliament (the social democrats, the left-republicans and the eco-socialists) joined these protests and were additional plaintives in the complaint. Interestingly, however, these same three parties would start governing in coalition in 2003, two years later, and would initiate an ambitious education reform process grounded in NPM ideas, that would introduce policies with a very similar approach to that of the mentioned decree.

The left-wing coalition governed Catalonia for two legislative periods: 20032006, and 2006-2010. In the first period, the ministry of education was in hands of the Left-Republican party, and NPM measures were not a central part of the education agenda. At the policy level, the government focused on the organization of a major National Conference of Education that ended up drawing up a broadly disseminated National Education Agreement. This agreement, which was subscribed by the government and most key educational stakeholders, would aim at defining the main guidelines and principles for the education reform that had to come

In the second period, the education reform came with the Ministry of Education in the hands of the Socialist Party (i.e. the social democrats) and with the approval of the first Catalan Education Act (LEC, for its acronym in Catalan). ${ }^{4}$ Surprisingly, this reform would introduce a strong NPM approach into the education system. It needs to be acknowledged that NPM ideas were not central in the Socialist Party education discourse at the time the government was formed. In fact, in the Socialist Party electoral program for the 2006 elections, references to NPM measures were absolutely marginal ${ }^{5}$. In terms of education governance proposals, the socialists put much more emphasis on the municipal decentralization of the education system. However, when the negotiations for the new education act started in the beginning of 2008 , the Catalan conservative party directly fought against the municipalisation proposal, stating they were against it because it could undermine the "national education system", weakening it due to a lack of sufficient resources at the municipal level (Stakeholder 1, February 27, 2013). However, some have argued that the conservative party's rejection of

\footnotetext{
${ }^{4}$ In Spain, there is a long tradition of introducing education reforms via the highest legislation possible: organic laws at the Spanish level, and 'autonomic' laws at the Catalan level.

${ }^{5}$ In the program, there were 20 educational objectives; only in objective 16 do we find references to anything that could be considered close to NPM: "Develop autonomous schools and teachers recognized socially and economically in order to improve the administration of education services" (Catalan Socialist Party, 2006).
} 
municipalisation was really related to their relatively low power and representation in local governments (ExMoE 1, May 15, 2013).

In any case, at that time, it was important that the new educational law, which would be the first one of its nature in Catalonia since General Franco died in 1975, generated sufficient consensus and had the support of the major parties. For this reason, the municipalisation idea was set aside, and both the socialist and conservative parties found common ground in the development of proposals based on 'school autonomy' and related NPM measures.

\section{Piloting school autonomy in Catalonia}

School autonomy was not a new theme in the Catalan education agenda at the time the negotiations for the LEC started. There was an important pilot experience initiated in 2005, known as the School Autonomy Project (SAP), that aimed at promoting both primary and secondary schools designing a context-sensitive "school autonomy plan" to fight against school failure and promote social cohesion. If approved, schools would receive a significant grant to be used as desired to achieve the objectives they set for themselves in the plan. In exchange, schools would need to be open to external evaluation and self-evaluation mechanisms, as well as to receiving training on strategic planning and leadership from the Catalan Education Ministry. The rights and duties of both the school and the Ministry were established in a sort of co-responsibility agreement that both parties would have to sign (Garcia-Alegre and Del Campo-Canals, 2012).

Between 2005 and 2009, 635 schools took part in the SAP. Despite the dimension it acquired, the project was run by a relatively small group of people, and coordinated by two very enthusiastic officials with a background that combined teaching and school inspection experience with organizational competencies (since both were involved in quality management and strategic planning policies in one of the three biggest public universities in Barcelona) (ExMoE 1, May 15, 2013, ExMoE 2, June 17,2013$)$. The team behind the SAP was publicly recognized on several occasions as the initiator of the school autonomy idea in the context of the LEC debate (Graells and Garcia 2009; Maragall and Colomé 2013). However, the conception of 'school autonomy' they advanced contained significant differences with the one that would end up being included in the law. The promoters of the SAP considered that autonomy and participation had to be combined strategically to guarantee school success. They believed in the importance of leadership at the school level for educational success, but they also thought that such leadership needed to be exercised democratically and be broadly distributed (ExMoE 1, May 15, 2013). Such a 
collegiate conception of school autonomy was also reflected in the above-mentioned 2006 National Education Agreement and in the 2006 socialist party electoral programme. All of them conceived the teachers' board and the school council as two key bodies whose functions should not be undermined by the authority of the school principal.

In contrast, the NPM regulations that were to follow would have a more managerial perspective on school autonomy and would emphasize the professionalization and empowerment of school principals at the expense of teachers' power. A range of factors and events, which we discuss below, would contribute to provoking this managerial shift in the new educational act.

\section{The position of key stakeholders in the reform}

The Catalan Education Act does not say much about 'education' or 'pedagogy' in strict sensu. It does not alter either the broader structure of the system, but, rather, it focuses on aspects of school governance. The promoters of the act articulate two main arguments to justify the focus of the reform on the 'school level'. The first argument says that previous education reforms in Spain had already introduced sufficient systemic changes, such as expanding compulsory education, strengthening the comprehensiveness of the system, improving the pedagogical approach, and guarantying the necessary resources for the system to work. However, despite these important changes, the performance of the education system continued to be mediocre (MoE 4, June 13, 2013; Stakeholder 2, February 28, 2013). The only dimension of the system that was left to be reformed, and that had the potential to revert this problem, was that of school organization (Garcia-Alegre and Del Campo-Canals, 2012). The second argument, although compatible with the previous one, says that LEC focuses on school governance because of a question of distribution of political competences between Catalonia and Spain. Specifically, the LEC had to focus on improving things at the 'school level' because this was one of the few dimensions of the school system in which the Catalan government had more room of manoeuvre at the legislative level (MoE 1, February 27, 2013; MoE 3, February 27, 2013; ExMoE 1, May 15, 2013; see also Vidal 2009).

However, the emphasis on 'school level' changes was not only a policy option by process of elimination; to many, it was also an inherently desirable policy. OECD/PISA has contributed enormously to construct such a preference among local policy-makers. In many ways, the PISA report is a key referential for Spanish and Catalan education policy-makers and politicians, independently of the party they come from (Bonal and Tarabini, 2013). PISA has made them become more aware of the 
'education quality' problem they face, but also to identify potential policy solutions. Several interviewees stated that the LEC took ideas on school autonomy and school leadership from OECD, because PISA - along with other OECD products - relates these policy options to more effective education systems (MoE 1, February 27, 2013; MoE 2, May 16, 2013). In fact, OECD officials advocating for school autonomy were regular speakers at conferences and in courses organized by the Ministry, 6 and even one of them worked as an external advisor to the School Autonomy Project mentioned above (ExMoE 1, May 15, 2013).

When it comes to understanding the managerial focus that was imposed on the LEC, we also need to consider the particular preferences of the Catalan Education Minister, Ernest Maragall, and his personal group of advisors, since they did not necessarily fit within the education agenda of the socialist party at that time. In fact, in a book he wrote on his experience as Education Minister, Maragall complains of the Socialist Party not having backed his reform ideas sufficiently (Maragall and Colomé 2013). However, for him, a politician with a long and well-established career who comes from a cultural-political elite and upper-class family, following his 'ideals' was more important than party discipline.

When he started his mandate, he did not have a strong background in education, but had strong opinions on public administration - and, specifically, on how the public sector was not working well on many levels, which some attribute to his strong links with ESADE (Stakeholder 1, February 27, 2013), a prestigious business school and one of the most active promoters of NPM ideas in the country. Maragall taught economic theory for a brief period in ESADE and is very close to its director, Francisco Longo, who has also specialized on 'school direction and management' and became Maragall's personal advisor in the context of the education reform (ExMoE 3, January 272014 )

In his public and private interventions, the minister constantly insisted on the need to make state apparatuses slimmer and more oriented toward results, and complained about previous governments' acceptance of the mediocrity that prevails in public schools7. He acknowledged that there are many "committed teachers", but also considered that "there are others that are simply settled in, too many of them" (Maragall, 2009, 18). For this reason he insisted on the importance of introducing teachers' incentives and evaluation schemes to improve schools. He also considered one of the fundamental problems in public schools to be the lack of a proper "owner" in

\footnotetext{
${ }^{6}$ See for instance: http://www.gencat.cat/educacio/congresexit/cat/programa.html

${ }^{7}$ See http://www.ara.cat/premium/societat/Ernest-Maragall-Nomes-millors-ciutadans 0 908909196.html
} 
charge, and that, to work properly, they would need to operate more like a private company8. According to him, deep changes of both a cultural and organizational nature would be necessary to modernize the Catalan education system (Maragall, 2009).

In Catalonia there is an organization of public school principals called Axia that aims at strengthening the role of school principals in the education system, and that was a key advocate of managerialism in the context of the LEC debate. In fact, the Minister Maragall valued the contributions of Axia- and other school principals -in the debate quite highly. According to him, school principals were one of the few stakeholders that really understood "the ambition and authenticity" of his reform agenda (Maragall and Colomé 2013, 118). Many agree in considering Axia a highly influential lobby in current Catalan education politics (MoE 3, February 27, 2013; Mo4 4 , June 13,2013$).{ }^{9}$ Its influence is based on its publication of numerous articles and studies, and on the organization of public events - usually attended by key decision makers10. In these spaces it disseminates the idea that strong school principals are key to achieving educational excellence. Independently of the quality of its ideas, Axia's voice is over-represented in education debates, as it is the only organized voice representing principals in the Catalan education field. However, there is more to this picture. Several Axia members are also officials in the Ministry of education, and some of them even occupy positions of high responsibility 11 . Thus, their influence in the Catalan government is not only external but also works in an organic way.

The teacher unions' opposition to the LEC content was fierce. In their opinion, the main proposals of the LEC undermined democratic control of schools and would lead to the privatization and detachment of the state from the provision of education. The intensity of their opposition to the government at that time, and against the figure of Maragall in particular, had no precedent in the democratic period: The unions organized four strikes in a period of eighteen months. The protests were not in vain, and contributed to the introduction of certain changes in a very first draft of the act, such as the elimination of a proposal to introduce new education modalities, such as

\footnotetext{
${ }^{8}$ Seehttp://www.tv3.cat/3alacarta/\#/videos/4539871 and http://www.elperiodico.cat/ca/noticias/opinio/ernest-maragall-mira-dels-centres-ningu-vol-ser-director240106

${ }^{9}$ See also http://www.laccent.cat/index.php/paisos-catalans/actualitat-social/item/3136qu\%C3\%A8-hi-ha-al-darrera-del-decret-de-plantilles-del-departament-d-ensenyament

10 http://elpais.com/diario/2007/11/10/catalunya/1194660442_850215.html

${ }^{11}$ For instance, the former President of Axia is the director of the division of support to principals in public schools of the Ministry, and another board member plays an important technical role in the Education Evaluation division.
} 
charter schools (exMoE 3, January 27 2014). In general, the belligerence was twosided. Minister Maragall considered the education system to have been captured by the unions and stated openly that one of the main aims of the reform was to undermine the unions' power and return it to the government, "where it belonged" (Maragall and Colomé 2013). The Ministry was in general not open to the unions' demands especially those against school autonomy and more hierarchical school management because they altered the essence of the reform excessively. At the same time, the unions did openly reject the idea of school autonomy because they argued it would lead to the 'atomization' and 'privatization' of the system, and to teachers' deprofessionalization. This made it easy for the Ministry and the mass media to publicly portray the unions as 'conservative', 'resistant to change', 'unwilling to dialogue', etc. (Lladonet, 2008). The tensions between both parties were accentuated due to the rapid pace that the government moved with to pass the reform, which did not fit within the tempo of the unions (Stakeholder 1, February 27, 2013)

Other education stakeholders did not have such a tense relation with the Ministry over the LEC. The organization of Catalan Christian Schools were not against the NPM measures introduced in the LEC draft, basically because their everyday activity would not be affected by them -in fact, their schools already functioned as the act would have the public schools function. For their part, progressive family associations and pedagogical movements - which have traditionally played an important role in the Catalan education arena - did not engage substantially in the NPM debate, and rather focused on other aspects. In their public reactions to the LEC, they emphasized the pedagogical dimension of school autonomy and, consequently, were supportive of those changes that would strengthen it (Biosca, 2009).

\section{The LEC approval and its main components}

After an intense parliamentary and extra-parliamentary debate, in July 10 2009, the LEC was passed. In the final weeks of deliberation, one of the parties in the government coalition, the eco-socialist party, retired its support of the LEC, while the conservative party - in the opposition - voted in favour. The eco-socialists argued that the LEC did not defend public education sufficiently and raised concerns about the potential equity implications of the type of school autonomy that was being promoted. ${ }^{12}$

The final reform passed was a law that focuses on the governance and organization of schools ${ }^{13}$ and that is structured around three main pillars: school

\footnotetext{
${ }^{12}$ See http://www.iniciativa.cat/icv/documents/1611

${ }^{13}$ Out of the 12 parts of the text, 8 refer to governance issues such as school autonomy, evaluation,
} 
autonomy, direction and evaluation. Each of these pillars was further developed in three corresponding decrees in the months after the act's approval.

The school autonomy decree (Decree 102/2010, August 3, 2010) promotes schools having greater autonomy in three main domains: financial management, school organization and pedagogy. On the basis of these three domains, each school must autonomously design its School Educational Project. Such a project should incorporate -as established in the SAP before- indicators of results so the project can be evaluated both internally and externally. If necessary, schools can receive additional public resources to develop their institutional projects.

According to supporters of the LEC, school autonomy is seen as a way of promoting a more relevant education and a curriculum that is adapted to the specific realities of the communities where schools operate. However, paradoxically, the pedagogical component is not central in the articles of the decree; rather, the text focuses on aspects of school management and, specifically on the role of the principal. According to some observers, the autonomy decree resembles much more a decree on school direction. In fact, in the decree we find 253 references to principals, and only 62 to teachers. At the same time, there are only 15 references to 'pedagogy' or pedagogy related aspects.

The so-called direction decree (Decree 155/2010 November 2, 2010) promotes the professionalization of the figure of the principal, establishes evaluation and promotion mechanisms for principals - including salary incentives - and gives them competencies in new domains, such as the hiring of teachers and school fundraising. The decree promotes the competitive selection of school principals on the basis of a 'direction project' candidates must elaborate. According to a ministry official, the direction decree aims at challenging the "horizontal culture that is rooted in the schools, which is very difficult to eliminate", and is "the most important barrier to modernizing schools" (MoE 6, July 13, 2013). In fact, in many Catalan and Spanish schools, the principal is still perceived as a rotating position and as "just another member of the teaching team" (Stakeholder 2, February 28, 2013). As with the autonomy decree, teachers are hardly mentioned, and when they are, they are not predominantly conceived as educational actors or agents of change. Specifically, out of the 46 references to teachers in the decree, 30 conceive of them as 'resources to be managed by the principal', or as 'workers', and only 14 as active members of the school organization.

Lastly, the evaluation decree (Decree 177/2010, November 23, 2010) focuses 
on the creation of an Evaluation Agency with numerous competencies over the evaluation of directors, schools, teachers' performance and students' results. This agency should have a public status, but be independent from the government to avoid potential conflicts of interest.

Interestingly, the last two decrees were approved just before Catalan elections were celebrated in November 28, 2010 (the evaluation decree being passed only five days before the elections). The Education Ministry rushed their passage because the expectations were not for the socialist party to win, which meant that the continuation of the NPM agenda in education would not be guaranteed. As we show in the following and last section of the case study, their concerns were certainly justified.

The conservatives are back (2010-present): NPM reform vs austerity policies?

On the same day that the LEC was passed, in the newsletter of his foundation, Jordi Pujol - the old leader of the Catalan conservatives and president of the country for 23 years (1983-2006)- congratulated the progressive government for its passage. Nevertheless, he also complained that when he was in power he had tried to introduce similar reforms but had faced the opposition of the socialists, who, paradoxically, were now promoting them ${ }^{14}$.

The conservatives won the 2010 elections comfortably, and inherited an education law they felt very comfortable with: it does not alter the conditions private schools enjoy to get public funding; it does not focus excessively on equity, and in many aspects it requires the public schools to emulate the functioning of the private sector. However, the new government is implementing the LEC in a very uneven and selective manner, basically implementing those NPM policies whose costs are zero or relatively low and that, at the same time, meet their political preferences. Such preferences would fit under what Apple (2006) calls 'conservative modernization', an ideology that combines, in an apparently contradictory way, on the one hand, the belief in market ideas such as school choice and the superiority of the private sector and, on the other hand, the promotion of further state control of schools via performance indicators, curriculum control, standards-setting, and nationally standardized evaluations.

The Conservative government has argued that it cannot implement the content of the LEC in a strict sense due to the budget constraints that the management of the financial crisis requires. For this reason, they cannot provide well-performing schools, principals and teachers with further economic incentives, as established in the different

${ }^{14}$ See: http://www.jordipujol.cat/ca/jp/articles/6463 
decrees explored above (MoE 5, July 13, 2013). Based on the same argument, the government has suspended the establishment of the independent external evaluation agency15, although motives of a non-economic nature may have also been in play here. The aversion of the conservative education minister to the possibility of creating an evaluation body that the ministry cannot control directly is well known ${ }^{16}$. Instead of creating such an agency, and far from the NPM ideal, the Minister has mandated its body of inspectors to adopt further evaluation responsibilities (ExMoE2, June 17, 2013), which reflects a more hierarchical and bureaucratic approach to evaluation and control.

At the same time, the conservative government has advanced a range of policies that undermine school autonomy, especially the pedagogic dimension of school autonomy. The SAP project has been frozen17 and its leaders fired due to its links with the former government. The current government considers the school educational project, that all schools must carry out under the law, as not central (it should be seen as a simple and general 'philosophy' of the school), whereas it considers the principal's project as the main tool to define the school strategy and management (MoE 5, July 13, 2013). At the same time, the government has promoted an ambitious programme on 'basic competencies' that establishes what primary and secondary schools should teach and how in the areas of Mathematics and Language.18 This initiative, together with on-going education reforms in Spain that favour the re-centralization of curriculum and introduce high-stakes standardized exams at the end of each level (cf. Ministerio de Educación, Cultura y Deporte 2013), contradicts the rhetoric of school autonomy in the pedagogy domain, and undermines the capacity of teachers to autonomously determine what should be taught and how in their schools.

From the wide NPM agenda regulated under the LEC, the conservative government is basically focusing on professionalizing and strengthening the role of principals. In this respect, they have promoted training programmes and accreditation mechanisms for principals, and established meritocratic procedures to select principals at the school level, which will reduce the power of the school council in this respect.

\footnotetext{
${ }^{15}$ See Decree 294/2011, March 8, 2011.

${ }^{16}$ Interview ExMoE2 (June 17, 2013). See also: http://www.elpuntavui.cat/noticia/article/-/5societat/392377-la-tisorada-frena-lavaluacio-independent-deleducacio.html?tmpl=component\&print=1\&page

17 There are no new autonomy agreements being signed with schools, and many of the schools that were already part of the SAP are not renewing the agreements due to the fact that the resources they provide are very scarce (MoE 7, July 13, 2013).

${ }^{18}$ See:http://premsa.gencat.cat/pres fsvp/AppJava/notapremsavw/detall.do?id=177449\&idioma=0\&depart ament $=4 \&$ canal $=5$
} 
They have also passed a new decree19 that allows principals to contribute to the hiring of part of their teaching staff based on the argument that this will contribute to building a more cohesive staff at the school level.

The strong opposition to NPM policies among mainstream teachers' unions has declined, as their current focus is on resisting the huge budget cuts that are affecting education and, in particular, teachers' working conditions. 'Temporary' teachers are those most affected by the NPM changes introduced by the conservative government and have created de facto organizations to protest against them. Since they cannot resort to the resource of strikes, as can conventional unions, they resort to innovative and disruptive repertoires of action, which are having quite an impact in the local media. On one occasion, they occupied the very popular tourist destination, the Sagrada Familia church, for one weekend, and another time they interrupted an Axia event where the personnel decree was being presented before its approval by the government - the latter event being another indicator of the strong affinity between the principals' lobby and the government.

\section{Discussion and conclusions}

\section{Explaining NPM policy-change}

In the last years, education reforms in Spain have focused on altering the management and organization of schools and, in particular, on the introduction of a NPM approach to the governance of education. The region where such an approach to educational change has been furthest developed at the regulatory level is Catalonia. There, NPM reforms have translated into the triangulation of three main policy measures: school autonomy, the professionalization of school management, and external evaluation. Catalonia has become a sort of NPM laboratory that is contributing to scaling-up similar education policies at the Spanish level. A range of factors, which we systematize below, has favoured such profound education changes in this region.

First, NPM changes fit with prevailing 'public sentiments' against bureaucracies and a generalized perception that the education system is mediocre. International assessments, such as PISA, have contributed greatly to introducing this sense of an urgent need for reform among the public and different political groups, and to the welcoming of policy changes that attempt to address such a situation.

Second, for political reasons of a different nature, school level reforms such as school autonomy are perceived as the missing piece in the modernization of the

\footnotetext{
${ }^{19}$ Published last April 10, 2013, pending to be approved
} 
education system, but also as the only dimension of the system in which the Catalan government could fully intervene without interferences from the Spanish government.

Third, we have focused on the impact of the particular policy preferences and charisma of the Catalan Ministry of Education at the time of the reform. Maragall was a very peculiar Minister, with strong convictions about NPM being the best formula to improve public schools, and willing to confront the powerful teachers' unions, and even factions of his own party, to advance his policy preferences. However, Maragall's ideas and decisions need to be contextualized within the evolution of contemporary social democratic thinking and, in particular, within the prevailing approach of social democracy to public sector reform. As happened in Nordic and Central European contexts before, the Catalan social democratic party ended up adopting NPM reforms because they perceived them as an effective way to dignify and modernize public education and fix its problems in a period in which it faces a legitimacy crisis.

Interestingly, the conservatives had tried to introduce similar managerial reforms before, but they did not have the same political capacity and legitimacy as the left to alter the way the public sector is regulated and organized. As observed by Klitgaard (2007, 174), 'social democratic governments engaging in unpopular social policy retrenchment may be more acceptable to the voters because they enjoy more credibility in protecting the system than right-wing market reformers'. In fact, the Catalan social democrats, together with other left-wing groups, fiercely opposed NPM educational policies in the beginning of the new century when the conservatives were ruling the country. However, just a few years later, they took power and ended up promoting an ambitious education reform precisely based on NPM ideas.

Nevertheless, NPM reforms in education have not necessarily been unpopular or only seen as a necessary evil in Catalonia. Resistance to NPM reforms has declined not only because social democrats were those behind them, but also due to the accomodationist effect of NPM ideas, such as school autonomy (cf. Linder, 1999). School autonomy, which is the flagship of NPM reforms in education, is an idea that is ambiguous enough to generate support among a broad range of audiences and ideologies. The social democrats see it as a way of promoting the public sector and making it more effective. The neoliberals consider it as a way to make the state apparatus slimmer and to introduce market logic into the public sector. The conservatives see it as a way to professionalize and hierarchize the management of schools. And progressive educators consider it as a way of introducing progressive pedagogies, relevant education and greater cohesiveness among teachers.

In the end, the core of the education reform battle was not about whether NPM ideas, like school autonomy, were right or not, or should be adopted or not, but about 
the concrete meaning these ideas should have, and about the way they should be regulated accordingly. Somehow, the fact that the unions rejected and opposed the adoption of any NPM based changes left them outside of this semiotic battle and facilitated the Ministry gaining legitimacy with an important segment of the population. In contrast to the unions, the school principals' lobby, Axia, took advantage of the juncture, both behind the scene and openly, and contributed to promoting a definition of school autonomy as inseparable from strong and professionalized management. This particular perspective on NPM has been reinforced by the conservative party, in power since 2011 , as it completely coincides with its 'conservative modernization' approach to education reform.

As a result, today, the dominant rationale behind the NPM reform in Catalonia is that school autonomy can only result from the efforts of a strong and professionalized school management. A school should have a strong leader, with a clear vision of where the school should go, and sufficient powers and authority to take it there. According to this rationale, the participatory organizational culture that has prevailed in the Spanish school system since the 1980 s is one of the main barriers to the modernization of the education system, and should be gradually substituted by more hierarchical forms of management. In this sense, one of the paradoxes of NPM reforms in Spain is that they are not being adopted because the system is too bureaucratic and hierarchical, but because it is apparently too democratic and horizontal.

\section{Paradoxes and absences in the NPM reform}

Catalan policy-makers and politicians, both from the right and the left, often argue in favour of NPM reforms by using PISA and OECD ideas as key references and legitimation assets. However, when doing so, they often translate OECD knowledge products in an interested and partial way. We explore, to finalize, a few examples of this. First, Catalan politicians use OECD arguments to support school autonomy as the best strategy to improve educational quality, but they tend to ignore that the OECD (2012) itself says that, beyond school-level reforms, system-level reforms also need to be considered for quality and equity purposes, especially in contexts like the Catalan one where school segregation is so high that it has become one of the main impediments for the system to improve its results. However, addressing this problem would mean confronting the powerful private school organizations and upsetting numerous middle class families who do not want to see their school choice options restricted (Bonal 2012). Thus, Catalan politicians may end up focusing on school level reforms because they are politically safer, despite not necessarily being more effective.

Second, school autonomy in Catalonia has ended up being conceptualized and 
regulated as the deconcentration of managerial tasks to the school level, at the same time that the 'pedagogic' meaning of school autonomy has been rather diluted. From an evidence-based policy perspective, this is unfortunate in the sense that pedagogic autonomy, and not autonomy in management/resource allocation, is the variable that is most positively correlated with school effectiveness according to OECD research (cf. OECD, 2011).

Third, in Catalonia, in the context of the school autonomy/NPM debate, school leadership has come to mean the promotion of strong school management. Among other implications, this means that a collective school education project becomes subordinated to a principals' personal project. Again, this is far from the specific OECD recommendations. As Pont $(2010$, p. 67,70$)$ notes, the "school leadership concept advocated by the OECD never alludes to a single person, but to a group of people working together [...] The reality of school management is that the responsibilities are many and cannot fall on one person. It is important to see management as a team where responsibilities are distributed".

To conclude, our research shows that the reasons for adopting NPM in the Spanish context are not so different from those prevailing in other European settings, however, similarly to what has been recently observed in other Southern European contexts (cf. Grimaldi and Serpieri 2013), the NPM reforms have been regulated and implemented in an uneven and paradoxical way. Political and economic arguments, which interact in the context of the always heterogeneous and contradictory Spanish educational policy field, are behind the partial, loose and paradoxical reform process described in this article. Furthermore, the selective and contested implementation of NPM reforms that we are witnessing in Catalonia is increasing the gap between regulatory aspirations and actual provision, a feature that still prevails in most Southern European scenarios.

At a more epistemological level, this article shows that the politics and economics of policy transfer are a useful approach to understand the way global policy ideas spread to different world locations. However, the case of NPM analysed here shows that semiotics, i.e. the way ideas and meanings are constructed, mobilized and received, are also key when it comes to understanding the recontextualization of global education policies and the way these policies work in practice. In other words, adopting a semiotic approach reveals itself as a necessary - and complementary - step to analyse the complexity of global education policy processes and, in particular, the way global policies are promoted, translated, resisted and, finally, selectively adopted in different educational settings. 


\section{References}

Apple, M. W. (2006). Educating the "Right" Way: Markets, standards, God, and inequality. New York: Routledge.

Ball, S. J. (1998). 'Big Policies/Small World: An introduction to international perspectives in education policy'. Comparative Education, 34(2): 119-130.

Beach, D., and R. B. Pedersen. (2013). Process-Tracing Methods: Foundations and Guidelines. Ann Arbor: University of Michigan Press.

Benito, R. y I. González. (2007). Processos de segregació escolar a Catalunya. Barcelona: Fundació Jaume Bofill. Biosca, C. (2009). La comunitat educativa es posiciona davant la LEC. Activitat Parlamentària 19: 20-24.

Bonal, X. and Rambla, X. (1996). Is there a Semiperipheral Type of Schooling? State, Social Movements and Education in Spain, 1970-1994, Mediterranean Journal of Educational Studies, 1(1): 13-27.

Bonal, X. (2012). Education policy and school segregation in Catalonia: the politics of non-decision making. Journal of Education Policy, 27: 401-421.

Bonal, X. and A. Tarabini (2013). The role of PISA in shaping hegemonic educationaldiscourses, policies and practices: the case of Spain. Research in Comparative and International Education, 8(3): 335-341.

Calero, J. (2006). La equidad en educación. Informe analítico del sistema educativo español. Madrid: CIDE.

Campbell, J. L. (2004). Institutional Change and Globalisation. Princeton: Princeton University Press.

Castles, F. (1993): 'Introduction' in Castles, F. (ed.): Families of Nations: Patterns of Public Policy in Western Democracies. NY: Oxford University Press: xiii-xxiii.

Clarke, J., Gewirtz, S and McLaughlin, E. (2000). New Managerialism, New Welfare? London: SAGE.

EURYDICE (2007). School Autonomy in Europe Policies and Measures. Brussels: Eurydice.

Fernández-Polanco, V. (2007). El Futuro Incierto de la Enseñanza Pública. A Parte Rei. Revista de Filosofía. 50: 1-2.

Ferrera, M. (1996). The "Southern Model» of Welfare in Social Europe, Journal of European Social Policy, 6(1): 17-37.

Fine, B. (2006). The New Development Economics: After the Washington Consensus. London: Zed Books.

Frías del Vall, S., (2006). Los consejos escolares de centro. Revista del Consejo Escolar del Estado, 1: 8-14.

Garcia-Alegre, E. and Del Campo-Canals, M. (2012). ¿La corresponsabilidad es una estrategia de éxito? Revista de Educación, número extraordinario, pp. 220-248.

Gómez Llorente, L. (2006). La participación. Revista del Consejo Escolar del Estado, 1: 18-26.

Graells, J. and I. Garcia. (2009). Estratègies clau per a la millora de l'èxit educatiu a Catalunya. Projecte per a la millora de la qualitat dels centres educatius (PMQCE) . Available at: http://www.gencat.cat/educacio/congresexit/cat/video.htm 
Grek, S. (2007), 'Governing by numbers: the PISA Effect'. Journal of Education Policy, 24(1), 23-37.

Grimaldi, E., and R. Serpieri. 2013. Jigsawing Education Evaluation. Pieces from the Italian New Public Management Puzzle. Journal of Educational Administration and History 45(4): 306-335.

Gunter, H. M., and G. Forrester. (2009). School Leadership and Education PolicyMaking in England. Policy Studies 30 (5): 495-511.

Hendriks, F., and Pieter Tops. (2003). Local Public Management Reforms in The Netherlands: Fads, Fashions and Winds of Change. Public Administration 81(2): 301-323.

Haque, M. S. (1996). 'Public Service Under Challenge in the Age of Privatization. Governance, 9(2), 186-216.

Hood, C. and Peters, G. (2004). The Middle Aging of New Public Management: Into the Age of Paradox? Journal of Public Administration Research and Theory, 13(3), 267-282.

Hudson, C. (2007). Governing the Governance of Education: The State Strikes Back? European Educational Research Journal 6(3): 266-282.

Kalimullah, N.A, Ashraf, K.M., Ashaduzzaman, M.N. (2012). New Public Management: Emergence and Principles. BUP Journal, 1(1): 1-22.

Klitgaard, M. B. (2007). Why Are They Doing It? Social Democracy and Marketoriented Welfare State Reforms. West European Politics 30(1): 172-194.

Linder, S.H. 1999. Coming to terms with the public-private partnership: A grammar of multiple meanings. American Behavioral Scientist 43(1): 35-51.

Lladonet, J. (2008). Crónica del Seminario. In Polo. P. and A. Verger. (eds). Educación, Sindicalismo y Globalización, Palma: Escola de Formació en Mitjans Didàctics. 5-22.

Maragall, E. (2009). Com governem l'educació. Minister of Education Conference, Palau de la Generalitat, Barcelona, 21/10/2009.

Maragall, E. and Colomé. F. (2013). Escola Nova, Poble Lliure. Barcelona: RBA

Maroy, C. (2009). Convergences and Hybridization of Educational Policies Around 'post-bureaucratic' models of Regulation. Compare 39(1): 71-84.

Martens, K., A. Nagel, M. Windzio, and A. Weymann. 2010. Transformation of Education Policy. The Impact of the Bologna Process and the PISA Study in Comparative Perspective. Basingstoke: Palgrave-Macmillan.

McLaughlin, K., Osborne, S.P and Ferlie, E. (2001). New Public Management: Current Trends and Future Prospects. New York: Routledge.

MECD (2012). Datos y cifras. Curso escolar 2012-13. Madrid: MECD.

Ministerio de Educación, Cultura y Deporte (2013). Proyecto de Ley Orgánica para la Mejora Educativa. Available at: http://www.mecd.gob.es/servicios-al-ciudadano$\mathrm{mecd} / \mathrm{dms} / \mathrm{mecd} / \mathrm{servicios-al-ciudadano-mecd/participacion-}$ publica/lomce/20130517-aprobacion-proyecto-de-ley.pdf

OECD. (2011). School autonomy and accountability: Are they related to student performance? Pisa in Focus 9.http://www.oecd.org/pisa/48910490.pdf

OECD (2012). Equity and Quality in Education: Supporting Disadvantaged Students and Schools. Paris: OECD.

Osborne, D., and Gaebler, T. (1993). Reinventing government: how the entrepreneurial spirit is transform in the public sector. New York: Plume.

Peck, J., and Theodore, N. (2010). Mobilizing policy: models, methods, and mutations. 
Geoforum, 41(2), 169-74.

Pont, B. (2010). Liderazgo y autonomía del centro escolar: perspectivas internacionales. Participación educativa, 13: 62-72.

Reguzzoni, M. (1994). Experiencias y experimentaciones en torno a la autonomía escolar en los países europeos. En A. Villa (Ed.) Autonomía Institucional de los Centros Educativos. Bilbao: ICE de la Universidad de Deusto.

Santos, B. de S. (1991). State, wage relations and social welfare in the semiperiphery: the case of Portugal. Coimbra: Centro de Estudos Sociais.

Sleegers, P, and A. Wesselingh. (1995). Dutch Dilemmas: Decentralisation, School Autonomy and Professionalisation of Teachers.Educational Review 47(2): 199207.

Sotiropoulos (2004): Democratization, Administrative Reform and the State in Greece, Italy, Portugal and Spain: Is There a 'model' of South European Bureaucracy? The Hellenic Observatory. The European Institute. Available at :http://eprints.Ise.ac.uk/5682/1/Sotiropoulos17.pdf

Steiner-Khamsi, G. (2010). The Politics and Economics of Comparison. Comparative Education Review, 54(3), 323-42.

Tolofari, S. (2005). New Public Management and Education. Policy Futures in Education 3(1): 75-89.

Verger, A., M. Novelli and H. K. Altinyelken (2012). Global Education Policy and International Development: An Introductory Framework. In Verger, A., M. Novelli and H. K. Altinyelken (Eds.). Global Education Policy and International Development: New Agendas, Issues and Policies. London: Continuum. 3-32

Vidal, F. (2009). La Llei d'Educació i el sistema educatiu. Activitat Parlamentària, 19: 819.

Vigoda, E. (2003). New Public Management in Jack Rabin (Ed.). Encyclopedia of Public Administration and Public Policy, Vol. 2, New York: Marcel Dekker.

Villarroya, A. and Escardíbul, J.O. (2008). Políticas públicas y posibilidades efectivas de elección de centro en la enseñanza no universitaria en España. Profesorado. 12(2): 1-26.

Wiborg, S. (2013). Neo-liberalism and universal state education: the cases of Denmark, Norway and Sweden 1980-2011. Comparative Education 49(4): 407-423. 